\title{
The Ripple Effects of Online Marketplace Bans
}

\author{
Ariel Ezrachi*
}

\begin{abstract}
The strive for tighter control of distribution, quality and price - has led an increasing number of producers to include restrictions on the use of online marketplaces in their selective distribution agreements. This paper considers the effects of such restrictions and the legal approach they call for. While acknowledging the legitimacy of proportionate restrictions on distribution, the article illustrates how an absolute ban on the use of online marketplaces may have a detrimental effect on market transparency, price competition, entry and expansion. The discussion illustrates how the legitimate interests of producers may be protected through less onerous means, without the increase in consumers' search costs and the dampening of price competition. With that in mind, it is argued that these restrictions should be analysed on a case-by-case basis and should not benefit from the Vertical Block Exemption. Furthermore, the article considers whether absent proportionality and objective justification, the harmful effect of online marketplace bans, justifies their condemnation as anticompetitive by object.
\end{abstract}

Key words: e-commerce, online marketplace bans, selective distribution, vertical restrictions

JEL codes: K21, L41, L42, L81

\section{Introduction}

E-commerce has brought us all closer to the promised land of competition - where ample choice, better quality and lower prices reside. Our online environment is seemingly delivering constant waves of innovation and competitive pressure. It has led to reduced barriers to entry, increased market access, increased market transparency and lower search costs.

And yet, behind the façade of competition, a range of strategies exist, which may undermine these developments - limiting transparency, price competition, choice and access to markets. Indeed, following the wave of innovation and competitiveness introduced by e-commerce, increasingly powerful anti-competitive undercurrents have come into play.

At times, anti-competitive strategies may be unilateral, and include behavioral discrimination or exclusionary practices. ${ }^{1}$ At other times, anti-competitive outcomes may result from coordinated

\footnotetext{
* Slaughter and May Professor of Competition Law, The University of Oxford. Director, Oxford University Centre for Competition Law and Policy. The research, on which this paper is based, was supported by the Computer and Communications Industry Association (CCIA). I am grateful for comments received on earlier draft of this article from participants at the "Competition in E-Commerce" Conference, Brussels, 2016. Thanks are also due to Sym Hunt for excellent research assistance. Views expressed in this paper and any errors or omissions are the author's own.

${ }^{1}$ Ingo Klauss and Nina Laskey, 'Germany: anti-competitive agreements - selective distribution systems' (2014) 35(2) European Competition Law Review 35(2) N6; Google (Case AT.39740).
} 
efforts, such as price fixing ${ }^{2}$ or algorithm-driven collusion. ${ }^{3}$ In addition, competition agencies have had to grapple with novel contractual frameworks that operate behind the scenes of ecommerce. Notable has been the investigation into, and condemnation of, the use of wide-parity clauses by online operators. ${ }^{4}$ Also noteworthy, are increasing concerns about restrictions imposed on sellers' use of online marketplaces (i.e. 'online marketplace bans').

In this article, we explore these latter restrictions, including the economic and legal implications of online marketplace bans. We seek to identify an adequate balance between, on the one hand, the interests of manufacturers in limitations on the use of online marketplaces, and on the other hand, the need to sustain a competitive online environment. The discussion opens with a review of the ways in which online marketplaces contribute to dynamic competition. Following this, we explore the role and scope of selective distribution agreements. Within this context, we consider the economic and legal consequences of online marketplace bans. The discussion illustrates their harmful effects and their inconsistency with the goal of promoting a competitive online environment. With this in mind, we note the inadequacy of a categorical exemption of online marketplace bans under the Vertical Block Exemption, and the need for case-by-case scrutiny.

\section{Setting the Scene - the Contribution of Marketplaces to Dynamic Competition}

The emergence of Internet sale hubs, such as online marketplaces, has transformed the online environment. These intermediate hubs bring together large numbers of sellers and buyers, and in doing so facilitate dynamic competition, both in relation to greater inter-brand competition, and in relation to intra-brand competition. ${ }^{5}$

Marketplace hubs differ in their remit and in the way that they operate. Some act as pure intermediates between the sellers and buyers - creating the forum in which horizontal competition between the sellers take place, and in which price and quality information is conveyed to customers. Others act as hybrid intermediates - providing a sales platform, and also operating as a retailer on the same platform. ${ }^{6}$ Marketplaces may also differ in the level of access that they provide for retailers. While some operate open marketplaces in which any seller may gain access as long as it satisfies base requirements, others operate closed marketplaces, where

\footnotetext{
${ }^{2}$ United States of America v. David Topkins (Case CR 15-00201 WHO); C-74/14 Eturas and others Court of Justice of the EU

${ }^{3}$ Ariel Ezrachi and Maurice E. Stucke, 'Artificial Intelligence \& Collusion: When Computers Inhibit Competition' U. Ill. L. Rev (forthcoming); Ariel Ezrachi and Maurice E. Stucke Virtual Competition - the promise and Perils of the Algorithm driven Economy (HUP 2016).

${ }^{4}$ Ariel Ezrachi 'The Competitive Effects of Parity Clauses on Online Commerce' [2015] 11/2-3 European Competition Journal 488-519

${ }^{5}$ Lukas Solek and Stefan Wartinger, 'Restrictions of Third-Party Platforms within Selective Distribution Systems' (2016) 39(2) World Competition Law and Economics Review 291, 293-4; CMA response to the call for evidence: Online Platforms and the EU Digital Single Market (23 October 2015), para 19, eBay Response to the Public Consultation on the European Commission's Review of the Vertical Restraints Regulation and Guidelines (28 September 2009), 7.

${ }^{6}$ By occupying both an upstream and downstream position they engage in vertical competition with the other sellers.
} 
access restrictions are imposed, and choice may subsequently be more limited. ${ }^{7}$ In addition, marketplaces differ in the type and quality of the interface that they offer, after sales care, and the ability to personalize the sales environment.

While different characteristics exist, one can nonetheless identify several overarching parallels between the marketplaces, and consider their contribution to competition at both consumer and retailer levels;

For the consumers, these hubs provide a transparent and easily accessible market place with ample choice and competition. They improve market transparency and information flows - they make it easier for users to compare offerings (on a computer, or on a mobile device) and identify the offer that best meets their needs, whether this be regarding price, or the attributes of the product. $^{8}$ Increased transparency supports allocative efficiency and the competitiveness of markets - resulting in downward pressure on price and better quality and services. ${ }^{9}$ This is because transparency reduces search costs and makes it harder for suppliers to take advantage of ill-informed customers who are subject to high information costs. ${ }^{10}$ The presence of wellinformed buyers who are aware of market offerings, encourages further investment in technology, quality and services - both online and in brick-and-mortar outlets.

In addition, online marketplaces also offer a number of distinct efficiencies for sellers. Notable is their contribution to the entry and expansion of small and medium size businesses. These retailers could have established their own websites, but may have found it impossible to successfully enter the market on their own. The use of a marketplace enables these retailers to benefit from demand-enhancing features and from reduced risk. This is also facilitated by the marketplace's reputation, payment guarantee and ease of transactions - which make the sale a simpler, more secure process. Furthermore, with the increased use of mobile platforms for shopping online, online marketplaces provide small and medium sellers with a valuable platform to reach the 'mobile customer'. Absent this bridge, many of these sellers would remain outside the mobile market as they lack the funds and scale to enable effective and trustworthy mobile application.

\footnotetext{
${ }^{7}$ For a more comprehensive review of the range of business models, see the European Commission's Preliminary Report on the E-commerce Sector Inquiry (SWD(2016) 312) (15 September 2016), [76]-[95].

8 J. Yannis Bakos, 'Reducing Buyer Search Costs: Implications for Electronic Market Places' (1997) 43(12) Management Science 1, 5.

${ }^{9}$ Note, for example, the UK Office of Fair Trading (OFT) in its investigation into hotel accommodation and online travel agents, where it noted that '[t]he Internet allows for a much swifter search and comparison across a wide variety of choice factors including price, dates, quality and location', and that '[t]he Internet brought about price transparency across the market, enabling consumers to identify the best deal,...' OFT Statement of Objections, Paras $1.14-1.15$, as cited in the Competition Appeal Tribunal judgment - Skyscanner Limited v Competition and Markets Authority Case No. 1226/2/12/14, 26 Sep 2014, [2014] CAT 16, 31-32.

${ }^{10}$ Ariel Ezrachi 'The Competitive Effects of Parity Clauses on Online Commerce' (2015) European Competition Journal 488; J. Yannis Bakos, 'Reducing Buyer Search Costs: Implications for Electronic Market Places' (1997) 43(12) Management Science 1, 13; Joseph E Stiglitz, 'Imperfect information in the product market' in R. Schmalensee and R. D Willig (eds), Handbook of Industrial Organisation (Volume 1) (Elsevier Science Publishers, 1989) 769; J. Yannis Bakos, ‘A Strategic Analysis of Economic marketplaces' (1991) MIS Quarterly 295.
} 
To illustrate the way in which online marketplaces mitigate cost risks and facilitate entry; consider the cost of online advertising. In general, to successfully reach its customers and inform them of its offering, a new entrant will have to invest in online promotion. Payments for such services are determined by the popularity of the search words used, and the number of clicks made on the advert - regardless of whether an actual sale took place. Failure to achieve a high conversion rate - that is, the ability to turn visitors into customers - can easily undermine entry and result in losses. On the other hand, a marketplace, benefiting from economies of scale, is better placed to effectively invest in search words and advertising on online search engines. Acting as a large and sophisticated advertiser, it can reach higher conversion rates which cannot be matched by small sellers. It can therefore facilitate cost effective access to customers, providing medium and small sized sellers the opportunity to compete in markets which would otherwise be dominated by the larger sellers. Indeed, in its recent Preliminary Report on the Ecommerce Sector Inquiry, the European Commission noted that marketplaces generate a high share of the online revenues of smaller retailers which use both their own websites, as well as marketplaces, for selling goods online. ${ }^{11}$

Online marketplaces enable new entrants and small companies to reach their target audience and to compete on equal footing as the larger online retailers. Sellers with market power will find it more difficult to benefit from distorted or limited information as to competing products and services. ${ }^{12}$ Being exposed to increased competitive pressure they are further incentivized to offer lower prices, better quality or better service.

\section{E-commerce and Selective Distribution Agreements}

Marketplaces provide customers with an enhanced infrastructure of effective connections between sellers and buyers, which help defy market distortions, market power and asymmetric information. As illustrated earlier, they help level the playing field, facilitating access and competition to the benefit of customers.

Against these benefits, some manufacturers have raised concerns as to the operations of online marketplaces. Their increased use has given rise to new challenges for some manufacturers that favour a controlled distribution system. Notable have been concerns raised by manufacturers as to their ability to maintain a uniform, consistent brand image and product and service quality. ${ }^{13}$ Also noteworthy are concerns raised by some manufacturers as to the rapid online price erosion,

\footnotetext{
${ }^{11}$ European Commission's Preliminary Report on the E-commerce Sector Inquiry (SWD(2016) 312) (15 September 2016), page 9.

${ }^{12}$ Status quo bias arose in the Commission's case involving Microsoft's Windows Media Player: Microsoft (Tying) (Commission decision of 16 December 2009 in Case C-3/39.530); FaceBook/WhatsApp (Commission decision of 3 October 2014 in Case COMP/M.7217), at [111], [124]; Office of Fair Trading, Completed Acquisition by Motorola Mobility (Google, Inc.) of Waze Mobile Ltd. (ME/6167/13), [57]-[61].

${ }^{13}$ The European Commission has made reference to internal studies prepared by manufacturers which identify these concerns: European Commission's Preliminary Report on the E-commerce Sector Inquiry (SWD(2016) 312) (15 September 2016), [145].
} 
which results from the improved price transparency and price awareness they foster. ${ }^{14}$ Indeed, in its Preliminary e-Commerce Report, the European Commission noted that as a reaction to the growth of e-commerce, producers "seek "tighter" control over distribution with a view to better controlling price and quality of distribution., 15

The strive for tighter control of distribution has led an increasing number of producers to use selective distribution agreements. Such use allows manufacturers to set qualitative criteria and restrict sales to unauthorized retailers, thus controlling market positioning, brand reputation, distribution quality, and information flows. ${ }^{16}$ Selective distribution may also enable manufacturers to control prices, albeit indirectly, by limiting the points of sale. ${ }^{17}$

When designed appropriately, selective distribution agreements can legitimately protect manufacturers', suppliers' and distributors' commercial interests, while safeguarding consumer interests. They may serve to protect the integrity of the distribution system, brand image, uniformity, quality and reputation. ${ }^{18}$ In addition, they may facilitate client-specific investments or know-how transfer. Like other vertical agreements, they may also serve to resolve the hold-up problem, minimize horizontal and vertical externalities, avoid the free-rider problem, and incentivize investment in demand-enhancing features and pre-sale services.

In Metro, ${ }^{19}$ the Court of Justice of the European Union (CJEU) considered the legal approach to selective distribution agreements and the use of objective qualitative criteria to safeguard quality and reputation. ${ }^{20}$ Such criteria, the Court held, would not be objectionable, when they are

\footnotetext{
${ }^{14}$ The European Commission has made reference to internal studies prepared by manufacturers which identify these concerns: European Commission's Preliminary Report on the E-commerce Sector Inquiry (SWD(2016) 312) (15 September 2016), [145].

${ }^{15}$ In its report, the Commission made reference to internal studies prepared by manufacturers which identified several challenges, including, among others: 'constant price pressure / constraint on the ability to increase prices due to improved price transparency and price awareness / minor price increases may lead to important losses... quick online price "erosion"... constant pressure to make a comprehensive / exhaustive range of products available... growing importance of keeping uniform, consistent brand image, product and service quality, consistent styles and prices, leading to a growing need for intensified control over distribution...' European Commission's Preliminary Report on the E-commerce Sector Inquiry (SWD(2016) 312) (15 September 2016), page 9.

${ }_{16}^{16}$ European Commission's Preliminary Report on the E-commerce Sector Inquiry (SWD(2016) 312) (15 September 2016), [209], page 9.

${ }^{17}$ European Commission's Preliminary Report on the E-commerce Sector Inquiry (SWD(2016) 312) (15 September 2016), page 9, [217]; In its report the commission also noted how 'several retailers complained about the lack of transparency and objectivity of the selection criteria used by the manufacturers to choose the members of their distribution network. In particular a number of retailers that qualify themselves as "discount" retailers raised concerns. These retailers suggest that even if they complied with all quality criteria, the suppliers would refuse their admission to the network due to the low retail prices they set for the products. Due to high price transparency online, these retailers would be seen by manufacturers as driving product prices down, thereby putting at risk the margins of many other authorised retailers in the distribution network.' [229]-[230].

${ }^{18}$ For a more comprehensive review of benefits and drawbacks, see the Guidelines on Vertical Restraints (2010/C 130/01), [100]-[109].

${ }^{19}$ Case 26/76 Metro SB- Großmärkte GmbH \& Co. KG v Commission [1977] ECR 1875, [1978] 2 CMLR 1

${ }^{20}$ Case 26/76 Metro SB- Großmärkte GmbH \& Co. KG v Commission [1977] ECR 1875, [1978] 2 CMLR 1, [20], [21].
} 
proportionate and in line with the nature of the product. ${ }^{21}$ On the other hand, when the criteria go beyond what is necessary, including quantitative restrictions, or non-objectively justifiable criteria, they will come under the scrutiny of Article 101 TFEU. ${ }^{22}$ In such instances, one would have to examine whether the vertical restraint may lead to foreclosure of suppliers or buyers, by raising barriers to entry or expansion, or soften competition and facilitate collusion between suppliers or between the distributors. As elaborated by the European Commission in its Vertical Guidelines:

Foreclosure, softening of competition and collusion at the distributors' level may harm consumers in particular by increasing the retail prices of the products, limiting the choice of price-service combinations and distribution formats, lowering the availability and quality of retail services and reducing the level of innovation of distribution. $^{23}$

In a market where individual distributors distribute the brand(s) of only one supplier, a reduction of competition between the distributors of the same brand will lead to a reduction of intra-brand competition between these distributors, but may not have a negative effect on competition between distributors in general. In such a case, if inter-brand competition is fierce, it is unlikely that a reduction of intrabrand competition will have negative effects for consumers. ${ }^{24}$

Accordingly, the treatment of selective distribution agreements ought to be cognizant of the range of restrictions in the agreement, their proportionality, objective justification and effect on the market. With this balance in mind, we turn to explore a range of restrictions on the use of the Internet and online marketplaces.

\section{The Spectrum of Restrictions on Internet Sales}

In striving to control quality, brand image, information flow (and at times the intensity of competition), manufacturers have introduced a range of restrictions on online sales into their selective distribution contracts. Such restrictions may range from qualitative criteria, to firm contractual restrictions. On the 'spectrum of restrictions' one may identify four key points. From the extreme absolute restriction of all online sales, to contractual marketplace bans, de-facto bans, and finally, qualitative criteria which do not result in a de-facto ban. Let us explore these four scenarios in more detail.

\footnotetext{
${ }^{21}$ Guidelines on Vertical Restraints (2010/C 130/01), [175].

22 T-88/92 Groupement d'achat Edouard Leclerc v Commission, [1996] ECR II-1961; Case 31/85 ETA Fabriques d'Ebauches v SA DK Investment and others; Case 243/83 SA Binon \& Cie v SA Agence et Messageries de la Presse.

${ }^{23}$ Guidelines on Vertical Restraints (2010/C 130/01), [101].

${ }^{24}$ Guidelines on Vertical Restraints (2010/C 130/01), [102].
} 


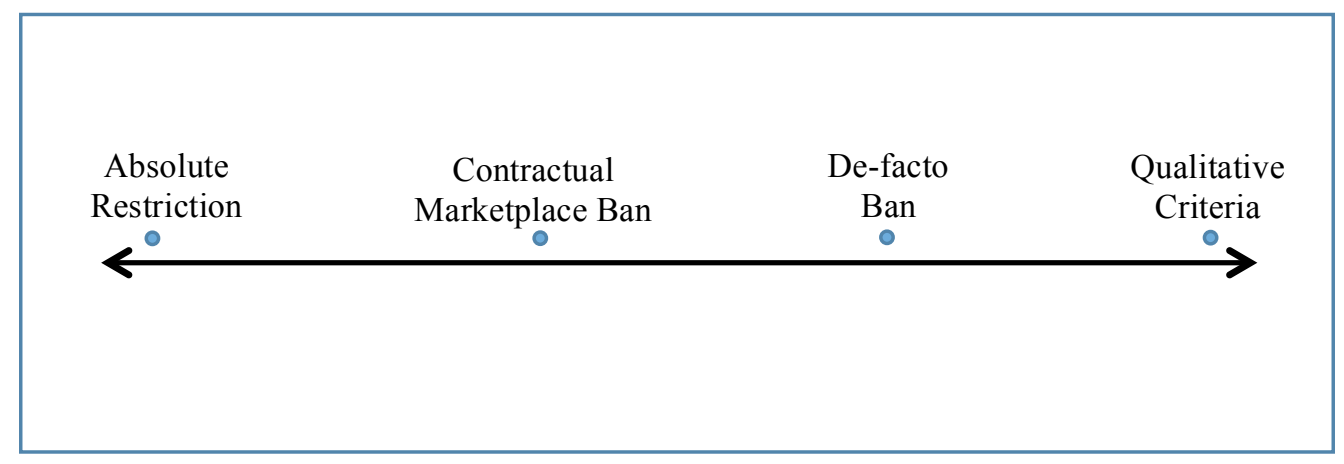

From a legal perspective, the first extreme point - that is, absolute restriction on Internet sales has been firmly identified as having the object of restricting competition. In Pierre Fabre $v$ Président de l'Autorité de la concurrence ${ }^{25}$ the CJEU held that an absolute ban on Internet sales amounted to violation by object. The case concerned restrictions on online sales in the distribution of cosmetics products which were not classified as medicines. The Court noted that for such products (non-prescription medicines), the need to provide individual advice, the desire to ensure protection against incorrect use of products, or to maintain a prestigious image, are not legitimate aims for restricting competition and do not form an objective justification. Further, with respect to the need to maintain the prestigious image of the products at issue, the CJEU held that:

The aim of maintaining a prestigious image is not a legitimate aim for restricting competition and cannot therefore justify a finding that a contractual clause pursuing such an aim does not fall within Article 101(1) TFEU. ${ }^{26}$

The condemnation of absolute Internet bans has been widely endorsed. ${ }^{27}$ As put by Alexander Italianer, then Director-General for Competition at the EU Commission: 'Due to such bans, retailers reach fewer consumers. Consumers, in turn, are robbed from having the greater choice and lower prices that competition on the Internet would give them. ${ }^{28}$ Also on point are recent comments made in relation to proceedings by the UK Competition and Markets Authority (CMA) against Ping Europe Limited. In a press release, the CMA stressed that ' $[\mathrm{t}]$ he Internet is an increasingly important distribution channel, and retailers' ability to supply via this channel

\footnotetext{
${ }^{25}$ Case C 439/09, [2011] 5 CMLR 31. For earlier case law, note Case COMP/37.975, PO/Yamaha in which the Commission condemned obligations whereby Yamaha's distributors had to contact Yamaha before exporting goods via the Internet, viewing such obligations as 'excessive', stating that, if the attempted justification was genuine, then there would be 'no reason' why the limitations should be limited only to online sales.

${ }^{26}$ Case C 439/09, [2011] 5 CMLR 31, [46].

${ }^{27}$ For a different view, questioning the legal basis in Pierre Fabre, see for example: Louis Vogel 'EU Competition Law Applicable to Distribution Agreements: Review of 2011 and Outlook for 2012' Journal of European Competition Law \& Practice, 2012, Vol. 3, No. 3, page 271, 273

${ }^{28}$ Alexander Italianer, Director-General for Competition, European Commission, 'Competition Policy in the Digital Age' (Speech, 7 March 2014) 47th Innsbruck Symposium- "Real sector economy and the internet - digital interconnection as an issue for competition policy" Available online at http://ec.europa.eu/competition/speeches/text/sp2014 01 en.pdf.
} 
should not be unduly restricted. This drives competition among rival retailers because they compete to attract consumers who are using the Internet to shop around for the best deals. Bans on Internet trading can be a problem if they seek to prevent retailers reaching a significant proportion of customers. ${ }^{29}$ This view is also reflected in the Commission's Vertical Guidelines which stipulate that contractual bans on passive online sales amount to hard-core restrictions of competition. ${ }^{30}$

Moving to the other end of the spectrum, one may find qualitative criteria which are introduced by the producer to ensure, among other things, the brand image, quality of distribution, customer services, promotion, and nature of display. As noted earlier, with reference to the Metro judgment, and in the Vertical Guidelines, a 'supplier may require quality standards for the use of the Internet site to resell his goods, just as the supplier may require quality standards for a shop, or for selling by catalogue, or for advertising and promotion in general. ${ }^{31}$ The Vertical Guidelines further note the possibility that 'a supplier may require that its distributors use third party platforms to distribute the contract products only in accordance with the standards and conditions agreed between the supplier and its distributors for the distributors' use of the Internet. $^{, 32}$

Having established the legal approach at both ends of the spectrum, we turn to consider the restrictions in the middle ground.

Contractual marketplace bans concern instances where the producer requires the retailer to only utilize the retailer's own approved website for sales and marketing, and prohibits the retailer from selling the products in question through online marketplaces. Similarly, albeit indirectly, de-facto marketplace bans concern instances where the use of certain standards and criteria in the agreement between producers and retailers, could lead to requirements that cannot be met by any marketplace. Such situation may arise when the criteria required by the producer are impossible to comply with, and cannot be addressed through existing technology. 'This may, for example, be the case, if the retailer's website has to appear under a domain name which contains

\footnotetext{
${ }^{29}$ Ann Pope, Senior Director, CMA (press release) 'CMA alleges breach of competition law by Ping' available online at https://www.gov.uk/government/news/cma-alleges-breach-of-competition-law-by-ping.; Also note earlier OFT decision in the Mobility Scooters Case which condemned restrictions on the online sale and advertising of prices for mobility scooters in the UK. (Roma-branded mobility scooters: prohibitions on online sales and online price advertising, OFT, CE/9578-12, 5 August 2013)

${ }^{30}$ Guidelines on Vertical Restraints (2010/C 130/01), [56].

${ }^{31}$ Guidelines on Vertical Restraints (2010/C 130/01), [54].

${ }^{32}$ Guidelines on Vertical Restraints (2010/C 130/01), [54] Commonly referred to as the logo clause. The paragraph continues with an example: 'For instance, where the distributor's website is hosted by a third party platform, the supplier may require that customers do not visit the distributor's website through a site carrying the name or logo of the third party platform.'
} 
the name of the retailer's business, if the website on which products are sold has to be operated by the retailer, or in case of a prohibition to sell via marketplaces that have their logo visible. ${ }^{33}$

How should one treat these restrictions? This question is pending before the CJEU in a preliminary reference ${ }^{34}$ in a case between Coty Germany GmbH ('Coty'), a perfume and cosmetic manufacturer, and an authorised distributor, Parfümerie Akzente GmbH ('Akzente'). Coty's distribution agreement expressly prohibited the sale of Coty products via third parties. When Akzente began selling Coty products on Amazon, Coty objected and sought to amend the distribution agreement so as to require that all Internet sales be organized through an 'electronic shop window', which must not affect the luxury image of the goods, and to ban Internet sales via a third party. Akzente's refusal to agree to these changes led to legal proceedings at the cartel law division of the OLG Frankfurt am main, which in turn referred the matter to the CJEU, asking, among others, as to the adequate treatment of online marketplace bans and their compatibility with article 101 TFEU.

While the Court has yet to deliver its ruling on the matter, the European Commission has published its views in its recent Preliminary e-Commerce Report. ${ }^{35}$ The Commission noted that the impact of de-facto and contractual online marketplaces and, consequently, the importance of marketplace bans, vary significantly between Member States and product categories. ${ }^{36}$ The Commission distinguished these bans from absolute restrictions on Internet sales, as the former do not exclude the use of the retailer's own website. ${ }^{37}$ Accordingly, it opined that the ruling in Pierre Fabre is not on point. Subsequently, in line with its earlier approach that was communicated in 2010 - at the time when the Vertical Block Exemption was adopted ${ }^{38}$ - the Commission concluded that online marketplace bans should not be considered 'hardcore restrictions within the meaning of Article 4(b) and/or Article 4(c) of the Vertical Block Exemption Regulation', as they do not have as their object 'a restriction of the territory or the customers to whom the retailer in question may sell, or the restriction of active or passive sales to end users. ${ }^{39}$ The Commission left the door open for this issue to be re-visited, by stating that:

\footnotetext{
${ }^{33}$ European Commission's Preliminary Report on the E-commerce Sector Inquiry (SWD(2016) 312) (15 September 2016), [433]; note in this respect the logo clause (Guidelines on Vertical Restraints (2010/C 130/01), [54]) which provides such restriction as an example.

${ }^{34}$ Case C-230/16 Coty Germany GmbH vs. Parfümerie Akzente GmbH.

${ }^{35}$ European Commission's Preliminary Report on the E-commerce Sector Inquiry (SWD(2016) 312) (15 September 2016).

${ }^{36}$ European Commission's Preliminary Report on the E-commerce Sector Inquiry (SWD(2016) 312) (15 September 2016), [469].

${ }^{37}$ European Commission's Preliminary Report on the E-commerce Sector Inquiry (SWD(2016) 312) (15 September 2016), [469].

${ }^{38}$ Commission Regulation (EU) No 330/2010 on the application of Article 101(3) of the Treaty on the Functioning of the European Union to categories of vertical agreements and concerted practices.

${ }^{39}$ European Commission's Preliminary Report on the E-commerce Sector Inquiry (SWD(2016) 312) (15 September 2016), [472]; The Commission's approach rejects the view that a ban on online marketplaces forms a restriction on passive sales which adversely affect a separate customer group. On that view, see further: Lukas Solek and Stefan Wartinger, 'Restrictions of Third-Party Platforms within Selective Distribution Systems' [2016] World Competition Law and Economics Review, Volume 39 Issue 2 pp. 291-306
} 
This does not mean that absolute marketplace bans are generally compatible with European competition law. The Commission or National Competition Authorities may decide to scrutinize marketplace bans in agreements falling outside the application of the Vertical Block Exemption Regulation, either because the market share thresholds in Article 3 Vertical Block Exemption Regulation are exceeded, or because the agreements contain any of the listed hardcore restrictions in Article 4 Vertical Block Exemption Regulation. The Commission or National Competition Authorities may also decide to withdraw the benefit of the Vertical Block Exemption Regulation if in a particular case the marketplace bans restrict competition within the meaning of Article 101(1) TFEU and are incompatible with Article 101(3) TFEU. ${ }^{40}$

In what follows, we will reflect on the proposition that online marketplace bans should benefit from the Vertical Block Exemption, and should not be treated as having the object of restricting competition.

\section{Online Marketplace Bans - the Legal Framework}

It is evident that one needs to balance between vertical restrictions and free online competition, and to identify the adequate and optimal level of intervention. That is particularly so, considering that the EU is the largest e-commerce market in the world. ${ }^{41}$ With this in mind, we look at the European legal framework and the relevant legal pillars.

First, there is little controversy as to the significance of quality in distribution, and the right of manufacturers to introduce proportionate, necessary and objective criteria into their distribution network. Since the CJEU ruling in Metro, a consensus exists as to the legitimacy of such qualitative provisions. ${ }^{42}$

Second, as held by the CJEU in Pierre Fabre, maintaining a 'prestigious image' as such, is not a legitimate justification for restricting competition. ${ }^{43}$

Third, as held by the CJEU in a number of judgments, including Metro, L'Oréal and Pierre Fabre, criteria in a selective distribution agreement must be proportionate and not go beyond what is necessary for it to be deemed to pursue the legitimate aim in question. ${ }^{44}$

Fourth, under the principle of equivalence, any restrictions on online sales, which are not overall equivalent to the criteria imposed for the sales from brick and mortar shops, would be deemed to

\footnotetext{
${ }^{40}$ European Commission's Preliminary Report on the E-commerce Sector Inquiry (SWD(2016) 312) (15 September 2016), [473].

${ }^{41}$ European Commission's Preliminary Report on the E-commerce Sector Inquiry (SWD(2016) 312) (15 September 2016), [6].

${ }^{42}$ Case 26/76 Metro SB Großmärkte v Commission [1977] ECR 1875, [20]

${ }^{43}$ Case C-439/09 Pierre Fabre [2011] 5 CMLR 31, [46]

${ }^{44}$ Case 26/76 Metro SB Großmärkte v Commission [1977] ECR 1875, [20]; Case 31/80 L'Oréal [1980] ECR 3775, [15]-[16]; Case C-439/09 Pierre Fabre [2011] 5 CMLR 31, [41], [43]
} 
form a hardcore restriction. This would be the case when the restrictions would not pursue the same objectives and are not justified by the different nature of these two distribution modes. ${ }^{45}$

Fifth, the benefit of the Vertical Block Exemption 'should be limited to vertical agreements for which it can be assumed with sufficient certainty that they satisfy the conditions of Article 101(3) of the Treaty. ${ }^{46}$

Sixth, the European Commission and the Competition Authority of a Member State may withdraw the benefit of the Vertical Block Exemption when an agreement has effects that are incompatible with Article 101(3) TFEU. ${ }^{47}$

Seventh, Article 101(3) TFEU will apply, among other things, when the agreement in question improves distribution, allows consumers a fair share of the resulting benefits, and on the condition that it does not: '(a) impose on the undertakings concerned restrictions which are not indispensable to the attainment of these objectives; nor (b) afford such undertakings the possibility of eliminating competition in respect of a substantial part of the products in question.'

With these seven pillars in mind, one may question the Commission's conclusion in its Preliminary e-Commerce Report, according to which de-facto and contractual bans could benefit from the Vertical Block Exemption. Even when considering the Commission's finding that the importance of marketplaces varies between states and between product categories, ${ }^{48}$ are marketplace bans aligned with these seven legal pillars? Do they comply with the principle of equivalence? Do they improve distribution and generate efficiency gains $?^{49}$ Taking account of the CJEU holding that 'prestigious image' is not a legitimate aim for restricting competition, one may also question whether online bans protect a legitimate goal. ${ }^{50}$

\footnotetext{
${ }^{45}$ Guidelines on Vertical Restraints, para 56; Also note the ruling of the Schleswig Higher Regional Court in Casio and the ruling of the Berlin Court of Appeal on Scout satchels. Case report available online: http://eucompetitionlaw.com/german-court-gives-green-light-to-online-market-place-sales-in-non-selective-distributionnetworks/

${ }^{46}$ Retical 5, Commission Regulation (EU) No 330/2010 on the application of Article 101(3) of the Treaty on the Functioning of the European Union to categories of vertical agreements and concerted practices.,

${ }^{47}$ Recitals 5, 13, 14. Also note recital 15: 'In determining whether the benefit of this Regulation should be withdrawn pursuant to Article 29 of Regulation (EC) No 1/2003, the anti-competitive effects that may derive from the existence of parallel networks of vertical agreements that have similar effects which significantly restrict access to a relevant market or competition therein are of particular importance. Such cumulative effects may for example arise in the case of selective distribution or non compete obligations.'

${ }^{48}$ European Commission's Preliminary Report on the E-commerce Sector Inquiry (SWD(2016) 312) (15 September 2016), page 9

${ }^{49}$ On this latter question note the view of the German Bundeskartellamt according to which the "protection of the retailers from increased price competition which might be achieved by a marketplace ban did not improve distribution and created no efficiency gains within the meaning of Art. 101 (3) TFEU.' Page 5, Adidas (case summary, B3-137/12, 19 August 2014) and the Bundeskartellamt background paper on 'Vertical Restraints in the Internet Economy' (Meeting of the Working Group on Competition Law 10 October 2013).

${ }^{50}$ The CJEU will soon have an opportunity to clarify the matter in Coty, since the first of questions referred to it by the OLG Frankfurt am main, seeks to re-confirm this holding.
} 
Even if an absolute ban is deemed to contribute to improving the production or distribution, it is not clear how consumers receive a fair share of the resulting benefit. Furthermore, the indispensability and proportionality of an absolute ban is questionable. One would expect less restrictive measures or qualitative criteria to provide protection to the producers' interests, without undermining the competitive dynamics. That is so, in particular when online marketplaces can take active steps to address quality requirements. ${ }^{51}$

Taking together, these considerations raise doubts as to the likelihood that online market place bans would satisfy the conditions of Article 101(3) TFEU. Such doubts tilt the balance against these bans benefiting from the safe haven offered by the Vertical Block Exemption. After all, the Vertical Block Exemption stipulates clearly that its benefit 'should be limited to vertical agreements for which it can be assumed with sufficient certainty that they satisfy the conditions of Article 101(3) of the Treaty. ${ }^{52}$

Adding to the seven pillars discussed earlier is an eighth central pillar which concerns the scope of the object analysis under Article 101 TFEU. As held by the CJEU, in order to determine whether an agreement restricts competition by object, 'regard must be had to the content of its provisions, its objectives and the economic and legal context of which it forms a part." 53 'When determining the context, it is also necessary to take into consideration the nature of the goods or services affected, as well as the real conditions of the functioning and structure of the market or markets in question. ${ }^{54}$

This eighth pillar invites us to take a closer look at the economic context - the dynamics of online markets and the characteristics of the agreement in question - in order to determine the adequate legal approach to online marketplace bans.

\section{Object or Effect?}

The Internet has given us endless horizons of choice and information. Any seller can enter the 'online land' and set up a website to sell goods. You, the reader, can do so instantly using one of many services which will provide you with readymade templates, payment systems and more.

\footnotetext{
${ }^{51}$ Sennheiser (Bundeskartellamt - B7-1/13-35); The European Commission's Preliminary Report on the Ecommerce Sector Inquiry (SWD(2016) 312) (15 September 2016) at [458] notes that: 'Some marketplaces offer sellers the ability to design their own seller shop within a special area of the marketplace which can reflect the look and feel of a brand or to have specific "showrooms" dedicated to certain brands and designed in line with the suggestions of the brands.' (457) 'Some marketplaces also run programs which allow them to keep track which sellers are authorized sellers within a selective distribution system of a manufacturer in order to only allow sales via sellers which have been approved and which qualify for the selection criteria.'

${ }_{52}$ Preamble 5, Commission Regulation (EU) No 330/2010 of 20 April 2010 on the application of Article 101(3) of the Treaty on the Functioning of the European Union to categories of vertical agreements and concerted practices, OJ L 102, 23.4.2010, p. 1-7)

${ }^{53}$ Case C-32/11 Allianz Hungária v Gazdasági Versenyhivatol [2013] 4 CMLR 25 [36]; Case C-67/13 Groupement des Cartes Bancaires v Commission [2014] 5 CMLR 22 [53]; Case C-172/14 ING Pensii [2015] 5 CMLR 15 [31]; Case C-286/13 Dole Food v Commission [2015] 4 CMLR 16 [117]; Case C-345/14 SIA 'Maxima Latvija' v Konkurences padome [2016] 4 CMLR 1 [17]; and, Case C-373/14 Toshiba Corp v Commission [2016] 4 CMLR 15 [26]-[29].

${ }^{54}$ Para 53, Case C-67/13 P Groupement des Cartes Bancaires.
} 
Entry has never been so easy. Or has it? One needs to distinguish between the ability to establish and operate numerous websites, and between successful entry. The former has little effect on the latter. Successful entry remains conditioned on the ability to reach customers, to inform them of the products and services and offer them a secure payment system and guarantee. As illustrated earlier, these functions are provided by the online marketplaces and platforms that level the playing field and map the options to potential buyers.

The endless online land may prove impossible to navigate without a clear map and tools to reach sellers from all ends. Absent such infrastructure, shoppers are likely to remain at the edge of the land where the key large visible sellers reside. Benefiting from their position, these established sellers may win the process of competition - not necessarily because of lower prices and better quality - but rather due to asymmetric, limited information, and lack of effective access to outside options.

This is even more so, when one considers the growing reliance on mobile shopping. From the user's perspective the mobile interface dictates a more rapid tour of the online land and reliance on existing applications and payment methods. Here one can identify additional barriers to entry which limit the presence of entrants and small and medium sellers. These may lack the funds, product variety, economies of scale, reputation, reliable payment systems and market positioning necessary for effective presence on mobile platforms. Online marketplaces, however, can remedy these shortfalls and provide them with an effective bridge to the mobile environment through the use of a trustworthy and well-functioning interface. They facilitate entry and expansion, reduce cost and risk, improve information flows in the mobile shopping environment and facilitate competition dynamic - where informed customers chose the option and seller which best suit their needs.

A ban on the use of marketplaces handicaps the ability of these sellers to be present online and on mobile platforms. With fewer sellers effectively competing, and large sellers benefiting from imperfect information, intra-brand competition is dampened. These effects are further aggravated when online marketplace bans become common. The increased use of bans by manufacturers creates a cumulative effect - further dampening inter-brand competition. The limited, or lack of, competition between brands on marketplaces reduces the competitive pressure they exert on each other. This is further aggravated by customers' need to spend more time finding and switching between different retailer's websites. With increased search costs, these customers will often opt for the default - the visible and established retailer.

With ever growing reliance on online sales and use of mobile platforms - bans may create a ripple effect which cements the position of larger retailers and dampens price competition. The significance of such an effect on our welfare cannot be overstated. Online shopping markets have 
increased in magnitude year by year. 55 'The online retail sector is the main driver of growth in European and North American retailing, achieving in Europe growth rates of 18.4\% (in 2014), $18.6 \%$ (2015) and expected rates in 2016 of $16.7 \%$ and in $2017,15.7 \%$. In comparison the annual growth rates for all types of retailing range between $1.5 \%$ and $3.5 \%$ pa. ${ }^{56}$

Our current shopping environment has evolved significantly in recent years, and so has our reliance, as customers, on platforms and gates to the endless online lands. We are accustomed to reaching our goal and information rapidly. Increased search costs, in this context may result in limited or no additional searches. When time is at a premium, users may opt for the leading default rather than multi-home and search other sellers and on other platforms. ${ }^{57}$

With these effects and the magnitude of online sales in mind, it is perhaps of little surprise that broad scale online bans form a rational unilateral profit maximizing strategy. A producer may be able to shield, to some extent, its product from the pressure of online competition and slow the decrease in price. Bans may also serve a vertically integrated producer to maximize its profit at the retail level. When market conditions give rise to interdependence of action between operators, each manufacturer may find it rational to follow the others' use of online marketplace bans. Importantly, this parallel action, when implemented unilaterally, will not be condemned under competition law. Still, the combination of vertical restraints aggravates their negative effect, and will likely result in further softening of price competition. ${ }^{58}$ In practice, online market place bans would often tilt the balance in favour of large retailers, making entry and sales more difficult for small retailers and limit price competition.

Considering these arguments, to what extent should the treatment of online marketplace bans call for a different approach than that taken by the CJEU in Pierre Fabre ${ }^{59}$ That judgment was confined to the specific facts of the case involving an absolute ban on Internet sales. Its rationale, however, when coupled with the market dynamics discussed earlier, can be extended to online

\footnotetext{
${ }^{55}$ For media coverage, see: 'Online shopping to grow by $£ 320 \mathrm{bn}$ in three years' The telegraph (8 June 2015) ; Mobile Moves in on Grocery Shopping' Media Post (January 22, 2015) ; 'Shopping by smartphone and tablet in UK increases by 18\%' The Guardian (15 Jan 2014)

56 'Online Retailing: Britain, Europe, US and Canada 2016' Centre for Retail Research. Available online: http://www.retailresearch.org/onlineretailing.php

57 Judy Wajcman, Pressed for Time: The Acceleration of Life in Digital Capitalism (Chicago: University of Chicago Press, 2015); see also Hartmut Rosa, Social Acceleration - A New Th eory of Modernity (New York: Columbia University Press, 2013)

${ }^{58}$ See the Guidelines on Vertical Restraints (2010/C 130/01) at [105]: 'In general, a combination of vertical restraints aggravates their individual negative effects. However, certain combi nations of vertical restraints are less anti-competitive than their use in isolation. For instance, in an exclusive distribution system, the distributor may be tempted to increase the price of the products as intra-brand competition has been reduced. The use of quantity forcing or the setting of a maximum resale price may limit such price increases. Possible negative effects of vertical restraints are reinforced when several suppliers and their buyers organise their trade in a similar way, leading to socalled cumulative effects.

${ }^{59}$ Case C 439/09, [2011] 5 CMLR 31. For earlier case law, note Case COMP/37.975, PO/Yamaha in which the Commission condemned obligations whereby Yamaha's distributors had to contact Yamaha before exporting goods via the Internet, viewing such obligations as 'excessive', stating that, if the attempted justification was genuine, then there would be 'no reason' why the limitations should be limited only to online sales.
} 
marketplace bans, since such restrictions are likely to significantly limit the Internet distribution possibilities and adversely affect the interest of consumers, those of competitors, the structure of the market and, in so doing, the competitiveness of the market as a whole. ${ }^{60}$

Of relevance here is the Bundeskartellamt's ASICS decision. ${ }^{61}$ In this case the German Competition Agency opined that the distribution system in question contained provisions that constituted restrictions of competition by object, among them, a restriction on the use of the ASICS brand names on third party's website in order to guide customers to the website of an authorised ASICS retailer, and a per se prohibition of supporting online price comparison engines. ${ }^{62}$ These restrictions where deemed to hinder access to sale channels that are of particular significance for end customers. They did not satisfy the pure qualitative benchmark in Metro and therefore could not escape the prohibition of Article 101 TFEU. $^{63}$

The Bundeskartellamt considered the legality of a ban on advertising or sales via online marketplaces. It noted that 'there were good reasons for assuming that the prohibition on the use of online marketplaces in the distribution system...was also a restriction of competition by object. ${ }^{64}$ It further elaborated on the considerations leading to this conclusion stating that it appears obvious that for many retailers, a per se prohibition of online marketplace in a selective distribution system leads to a major restriction on their possibility of making online sales to end customers.' The Bundeskartellamt noted that 'for small and medium-sized online shops in particular, presence in an online marketplace is decisive for customers being able to find them... $[\mathrm{T}]$ he per se prohibition of sales via online marketplaces is unlikely to have constituted an otherwise permissible quality requirement, since the business model of the "online marketplace" as such does not harm the product presentation..., 65

The Bundeskartellamt's reasoning reflects its earlier holding in Adidas, ${ }^{66}$ where it opined that 'a per se ban on sales via online marketplaces is not a qualitative criterion which is necessary to ensure the quality of the products concerned and the quality of their distribution. ${ }^{97}$ It noted that such bans undermine the ability of small and medium-sized retailers to access new customer

\footnotetext{
${ }^{60}$ On the aims of Article 101 TFEU, see for example: paras 38, 39, Case C-8/08 T-Mobile Netherlands and Others, [2009] ECR I-4529, [2009] 5 CMLR 11; paras 62-63 Case C-501/06 P etc GlaxoSmithKline Services Unlimited v Commission [2009] ECR I-9291, [2010] 4 CMLR 2

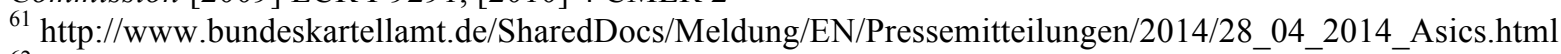

${ }^{62}$ Ref.: B2-98/11, Date of decision: 26 August 2015. Quote from the case summary in English, published by the Bundeskartellamt on 25 January 2016.

${ }^{63} \mathrm{Id}$, page 6,7

${ }^{64} \mathrm{Id}$, page 10

${ }^{65} \mathrm{Id}$, pages 10-12. In its decision the Bundeskartellamt also referred to equivalence considerations relating to offline sales. It noted that these 'are unlikely to have justified the prohibition on sale via online marketplaces. Specifically, there were no evident standards of comparison with the offline trading sector. Online marketplaces with the possibility of making an individual product search, in which a results list is produced from which the end customer can see the price of the respective offer and, if applicable, the evaluation of the store concerned, exist only on the Internet.' The principle of equivalence is laid down in paragraph 56 of the European Commission's Guidelines on Vertical Restraints.

${ }^{66}$ Adidas (case summary, B3-137/12, 19 August 2014)

${ }^{67}$ Page 3, Adidas (case summary, B3-137/12, 19 August 2014)
} 
groups and benefit from payment and demand enhancing services offered by the online marketplace. Further, such bans increase their advertising costs and reduce the likelihood that the retailer will reach their customers base, as 'the online shops of smaller retailers have little chance of appearing under their own URL in the upper section of the results list. ${ }^{68}$ These harmful effects, the Bundeskartellamt noted, are further increased by the fact that other important producers include similar restrictions in their distribution contracts. ${ }^{69}$

Against this view from the German Competition Agency, one should recall the European Commission's view which favours the effects approach. In its Preliminary e-Commerce Report the Commission did not separately address the question of "object". Rather, it focused its analysis on the application of the Vertical Block Exemption to such bans, and considered whether they amount to hardcore restrictions within the meaning of that regulation. In this context it mentioned in passing that it considered such bans not to have as their object the restriction of territory, customers, active or passive sales. This assertion builds on the Commission's view as stipulated in its 2010 Guidelines on Vertical Restraints according to which a 'supplier may require that customers do not visit the distributor's website through a site carrying the name or logo of the third party platform. ${ }^{, 70}$

With two conflicting approaches at hand, and pending the CJEU ruling in Coty Germany, ${ }^{71}$ uncertainty and inconsistency remain.

One may argue, however, that the market dynamics described earlier and the EU legal framework, may tilt the balance in favour of a condemnation of absolute marketplace bans as anticompetitive by object. Importantly, such an approach does not preclude possible exemption under Article 101(3) TFEU. ${ }^{72}$ What is does, however, is signal that, by and large, absolute bans on the use of online marketplaces are deemed anticompetitive and will only be accepted when they satisfy the criteria of Article 101(3) TFEU. The undertakings would have to show how the ban pursues a legitimate aim, compatible with that article. As held by the CJEU, maintaining a 'prestigious image' as such, is not a legitimate justification for restricting competition. ${ }^{73}$ When a ban does not generate efficiency gains to the benefit of consumers, and is not proportionate,

\footnotetext{
${ }^{68}$ Page 4, Adidas (case summary, B3-137/12, 19 August 2014)

${ }^{69} \mathrm{Id}$; Also note the discussion in the case of Sennheiser, where a ban on sales of audio products via Amazon Marketplace, eBay, or similar marketplaces came under scrutiny. Following an informal assessment, the Bundeskartellamt concluded that 'a manufacturer operating in the area of standardised electronics products for end consumers may not prohibit an authorised distributor from distributing these products via an online platform, at any rate if the platform is fully integrated in the electronic distribution system of another distributor also authorised by the manufacturer... The Bundeskartellamt therefore took the preliminary view that Sennheiser, which authorized Amazon as a distributor within the scope of its selective distribution system, may not prohibit distribution via the Amazon Marketplace platform by its other authorised contractors.' (case report, B7-1/13-35, 24 October 2013).

${ }^{70}$ Guidelines on Vertical Restraints, Para 54.

${ }^{71}$ Case C-230/16 Coty Germany GmbH vs. Parfümerie Akzente GmbH.

${ }^{72}$ In Case T-17/93 Matra Hachette v Commission [1994] ECR II-595, the General Court held that 'In principle, no anti-competitive practice can exist which, whatever the extent of its effects on a given market, cannot be exempted, provided that all the conditions laid down in [Article 101(3)] of the Treaty are satisfied ...'
} 
indispensable and justifiable, manufacturers would be advised to use less restrictive means such as qualitative criteria.

\section{Concluding remarks}

We are often told how the technological revolution will increase our welfare through greater transparency, communication, choice, and value. Indeed, in many cases this is correct. However, the online environment is not immune from market failures and counter measures. With our increased reliance on e-commerce we need to appreciate the way in which modern online market dynamics differ from those of yesteryear.

The evolution of online and mobile competition has led to the emergence of new entry and expansion barriers and the introduction of new means to defy them. In this economic context, online marketplaces play a valuable role - increasing transparency, reducing search costs, facilitating entry, mitigating retailers' risks and marketing costs, and supporting a more dynamic competitive environment.

Restrictions on the use of online marketplaces, imposed by producers, should be carefully appraised. With this in mind, it seems timely to suggest a recalibration of the 2010 Guidelines on Vertical Restraints. The centrality of the intermediates, their investment in demand-enhancing features and the role they play in supporting a competitive environment have evolved over the years and may well justify a more nuanced approach when delineating the scope of the Vertical Block Exemption.

The conceptual justification for the proposed re-calibration stems from the fundamental principle according to which the Vertical Block Exemption 'should be limited to vertical agreements for which it can be assumed with sufficient certainty that they satisfy the conditions of Article 101(3) of the Treaty. ${ }^{, 74}$ As illustrated, regardless of the popularity of online platforms in some jurisdictions, absolute marketplace bans are likely to reduce competition, limit access and generate a ripple effect which would undermine the competitive dynamics. While some marketplace bans may benefit from individual exemption on a case by case basis, as a category they cannot be deemed proportionate and assumed with sufficient certainty that they satisfy the conditions of Article 101(3) TFEU.

One would therefore urge the Commission to reassess the framework outlined in Paragraph 54 of its Guidelines on Vertical Restraints and narrow its scope. ${ }^{75}$ With the increased centrality of online marketplaces, the current framework as set in the paragraph is overly wide. A fine-tuned account of the acceptable restrictions could help support a more competitive online environment. For instance, should a supplier be able to impose a ban on the use of online marketplace on one of its retailers/distributors (which, for example engages in heavy discounting online) but not on

\footnotetext{
${ }^{74}$ Preamble 5, Commission Regulation (EU) No 330/2010 of 20 April 2010 on the application of Article 101(3) of the Treaty on the Functioning of the European Union to categories of vertical agreements and concerted practices, OJ L 102, 23.4.2010, p. 1-7)

${ }^{75}$ Guidelines on Vertical Restraints, Para 54
} 
others? Can a ban be justified if the producer itself is selling through the online marketplace, but is keen to restrict price competition from its distributors? In what circumstances would the use of a platform carrying the name or logo of the third party be deemed to undermine the interests of the producer?

Beyond the above fine-tuning, an overreaching question remains - whether online market place bans should be treated as hardcore restrictions which would lead to the exclusion of the agreement from the scope of application of the Vertical Block Exemption. When one considers the scope and application of the Vertical Block Exemption, marketplace bans may fit the existing framework for "hardcore restrictions of passive selling in view of the capability of these restrictions to limit the distributor to reach more and different customers. ${ }^{, 76}$ Taking account of the way in which such bans may limit entry and access to customers, online marketplace bans could be viewed as de-facto 'agreeing that the distributor shall limit its proportion of overall sales made over the internet. ${ }^{, 77}$ Such approach will align the treatment of online market place bans with that of Dual Pricing (paying different prices online and offline). The Commission considers the latter to form hardcore restrictions,${ }^{78}$ due to them 'limiting the retailer's online sales and hinder access to more and different customers online. ${ }^{79}$ That same reasoning could apply to online market place bans, as they too limit the reach of retailers and hinder access to customers.

The consideration of whether online market place bans form hardcore restrictions is naturally entwined in the discussion on the effects and object approach. The CJEU ruling in Coty Germany $^{80}$ will undoubtedly offer valuable clarification on this matter. Notwithstanding that holding, the dynamics of modern digital markets and the likely effects of absolute online marketplace bans raise sufficient concerns, warranting a more nuanced application of the Vertical Block Exemption, a recalibration of Paragraph 54, and a move toward a case-by-case scrutiny of online market place bans.

\footnotetext{
${ }^{76}$ Guidelines on Vertical Restraints, Para 52

${ }^{77}$ Guidelines on Vertical Restraints, Para 52.

${ }^{78}$ Guidelines on Vertical Restraints, Para 52, 64

${ }^{79}$ European Commission's Preliminary Report on the E-commerce Sector Inquiry (SWD(2016) 312) (15 September 2016), [542].

${ }^{80}$ Case C-230/16 Coty Germany GmbH vs. Parfümerie Akzente GmbH.
} 